\title{
COUNTERMEASURE POLICY ON THE SAMHO BROTHER BENZENE SHIP ACCIDENT
}

\section{Chin-Long Lin}

Department of Marine Environmental Informatics, National Taiwan Ocean University. Keelung, Taiwan, R.O.C., hujh@mail.ntou.edu.tw

Jian-Hwa Hu

Department of Marine Environmental Informatics, National Taiwan Ocean University. Keelung, Taiwan, R.O.C.

Follow this and additional works at: https://jmstt.ntou.edu.tw/journal

Part of the Aquaculture and Fisheries Commons

\section{Recommended Citation}

Lin, Chin-Long and Hu, Jian-Hwa (2010) "COUNTERMEASURE POLICY ON THE SAMHO BROTHER BENZENE SHIP ACCIDENT," Journal of Marine Science and Technology. Vol. 18: Iss. 2, Article 1.

DOI: $10.51400 / 2709-6998.2314$

Available at: https://jmstt.ntou.edu.tw/journal/vol18/iss2/1

This Research Article is brought to you for free and open access by Journal of Marine Science and Technology. It has been accepted for inclusion in Journal of Marine Science and Technology by an authorized editor of Journal of Marine Science and Technology. 


\section{COUNTERMEASURE POLICY ON THE SAMHO BROTHER BENZENE SHIP ACCIDENT}

\section{Acknowledgements}

Special thanks would give to those who participated in the entire rescue mission and to the reviewers of this paper for their comments and kind helps. Mr. Ted Knoy is also appreciated for his editorial assistance. 


\title{
COUNTERMEASURE POLICY ON THE SAMHO BROTHER BENZENE SHIP ACCIDENT
}

\author{
Chin-Long Lin* and Jian-Hwa Hu*
}

Key words: ship mishap, benzene, oil spill, countermeasure policy.

\begin{abstract}
On October $10^{\text {th }}, 2005$, the chemical ship SAMHO BROTHER mishap occurred in the Taiwan Strait while transporting a cargo of benzene. Explosive approach was applied but failed, causing the ship wreck sank to a depth of $70 \mathrm{~m}$. Oil spill was recovered in a small amount, leaving about 50 tons of the fuel remained. On the other hand, environmental monitoring at the site of the accident revealed that almost all of the great amount of $3140 \mathrm{~m}^{3}$ benzene remains stored in the nine tanks on the ship and further actions upon such a unique event in the history are urgent. Some possible ways for countermeasure policy are analyzed and discussed subjectively and objectively based on considerations of the ship owner and the government of the Republic of China at Taiwan. They are to leave the ship at its current site, to salvage the ship and its cargo, to extract the remaining fuel oil and benzene, and to blow up the ship in an underwater explosion.
\end{abstract}

\section{INTRODUCTION}

Ship mishaps occur from time to time throughout the history of mankind. In fact, ships sunken at sea during wars are even numerous. In ancient times, aside from the immediate loss of life and property, possible ensuing problems from the accident are limited. However, technological advances have not only increased marine transportation capacity, but have also led to an increasingly diverse range of goods being carried internationally. These commodities include substances leading various controversies. In recent years, there had been some major ship wrecks in which cargo including radioactive nuclear fuels as well as other chemical and metal substances spilled into the sea or sank to the sea bed. For example, the Russian submarine Kursk, sank to the bottom of the Barents Sea following an explosion on August $12^{\text {th }}$ of $2000[2,3,11$, 13] and attracted worldwide attention.

Paper submitted 11/12/07; revised 01/04/08; accepted 04/25/08. Author for correspondence: Jian-Hwa Hu (e-mail: hujh@mail.ntou.edu.tw).

*Department of Marine Environmental Informatics, National Taiwan Ocean University. Keelung, Taiwan, R.O.C.
Fuel spills are a common result when large fuel oil powered vessels encounter misfortune at sea. Such events can often result in extensive and long-term negative impacts on the coastal environment. On January $14^{\text {th }}, 2001$, the Greek cargo ship Amorgos struck a reef in southern Taiwan, causing a 1100 ton fuel spill that polluted 20 hectares of sea and severely damaged local marine ecosystem and fishery resources [6]. Since background information on marine life and resources was unavailable, there was insufficient evidence to confirm the damage, and hence claims for damages were significantly reduced. Undoubtedly, mishaps involving oil tankers have the potential for catastrophic environmental consequences. On March 24 ${ }^{\text {th }}, 1989$, America's Exxon Valdez encountered a calamity in the Alaskan Sea $[9,16,17]$, and on September $13^{\text {th }}$, 2002, the Spanish Prestige suffered a huge amount of fuel leakage $[1,4]$. Moreover, on February $7^{\text {th }}, 1977$, the Kuwaiti vessel Borag, which was carrying 32000 tons of crude oil, struck a reef and sank north of Taiwan, spilled at least 15000 tons of oil to pollute the entire northern coast of Taiwan. According to the background information regarding the regional ecosystem provided by the two nuclear power plants in northern Taiwan as part of a long term survey [5], the losses suffered by the fishing industry were estimated at 17.27 million USD for offshore fisheries, 2.6 million for coastal fisheries, 10 million USD for harvesting fisheries, and 2.61 million for the aquaculture, totaling 32.48 million USD [15] was justified to be paid off by the ship owner according to the international law.

Along with the development of the petrochemical industry and the growing demand for petroleum products, the weight of chemical cargo has increased substantially over the past decade. It is worth investigating whether marine exploration technologies are adequate for dealing with the aftermath of marine accidents when vessels carry chemicals. In July, 2005, M/T Kyokuyo-Maru, which was laden with benzene, collided with another ship, the $M / V$ Nikko Maru, near Japan, resulting in a fire, explosion, and two deaths among the respective crews with four crew members going missing [12]. After failing to control the fire, the Japanese Coast Guard and the Marine Disaster Prevention Center let the fire continue to burn up the remaining oil and benzene, before towing the ship $59 \mathrm{~nm}$ (nautical miles) from the coast and allowing it to sink 4,400 m to the bottom of the sea. The entire process took 8 days. This was the first recorded case of ship carrying benzene being 
wrecked by the approach to burn out the benzene on the surface of the sea, and then deal with the hull.

In October, 2005, a similar marine accident, involving the SAMHO BROTHER, a chemical cargo carrier loaded with benzene, occurred in the Taiwan Strait. The ROC government and experts from all over the world conferred intensely on the best strategy for minimizing environmental damage. Imitating the response adopted by the Japanese to a similar incident, the initial plan was to recover the oil spill at sea, and then blow up the ship wreck using explosives. Unexpectedly however, firing missiles from the air failed to achieve the desired result. The ship itself along with the large amount of benzene sank to the bottom of the sea. The problem has not been resolved, and remains there to this day. Further actions are deemed necessary to remove the sunken ship. This study retraces the event of the mishap and reviews the events involved in this disaster and the measures taken in response. Additionally, this study discusses the observation and evaluation of fuel oil spill as well as the methods and results for the detection of benzene leakage. In addition, feasible strategies for dealing with sunken ships lying on the ocean floor and carrying chemical substances are investigated and analyzed to attain the most practicable approach for removal of the dangerous material. A short note regarding this study has been published by Lin and $\mathrm{Hu}[10]$.

\section{EMERGENCY ACTIONS}

SAMHO BROTHER, a Korean chemical cargo ship weighing 2500 tons (see Table 1 for details) was steered from Yuso, Korean to Kaoshiung, Taiwan. At 00:30 on October $10^{\text {th }}$ in 2005 , at $25^{\circ} 01^{\prime} \mathrm{N}, 120^{\circ} 50^{\prime} \mathrm{E}, 9 \mathrm{~nm}$ from the coast of Taoyuan (Fig. 1), it collided with T. S. Hong Kong, a Nigerian cargo ship en route from Keelung to Hong Kong, on the port side near its stern.

After the collision, oil began to leak from the engine room of SAMHO BROTHER, and at 02:45, the captain gave the order to abandon ship. Fourteen crew members were rescued successfully by five surface cutters and two helicopters of the ROC-Coast Guard. Soon afterwards the ship capsized. Due to the high seas in winter, the Coast Guard sent cutters to safeguard the alarmed region two days later and found the ship with only its bow above water at 09:21 on the $12^{\text {th }}$ (Fig. 2(a)) at $120^{\circ} 48^{\prime} \mathrm{E}, 24^{\circ} 58^{\prime} \mathrm{N}, 2 \mathrm{~nm}$ from the collision site. The water depth there was 70-72 $\mathrm{m}$ while the ship had a length of $91 \mathrm{~m}$, meaning the ship would have been standing upright with its stern on the floor (Fig. 2(b)).

The ROC government established the Hazard Response Center (HRC) immediately after then. Because the vessel was carrying approximately $3140 \mathrm{~m}^{3}$ of benzene and according to the $\log$ book the total amount of oil of various kinds was 81 tons, the HRC announced access restrictions on the area within a $5 \mathrm{~km}$ radius of the sunken ship. Vessels were sent to safe areas near the site each day to gather air and sea water samples for testing. Additionally, responsibility was placed on the ship
Table 1. SAMHO BRATHOR ship information.

\begin{tabular}{|c|c|c|}
\hline Ship's Name (English) & \multicolumn{2}{|c|}{ SAMHO BROTHER } \\
\hline Port of Registry & \multicolumn{2}{|l|}{ JEJU } \\
\hline Flag & \multicolumn{2}{|l|}{ KOREA } \\
\hline \multirow{4}{*}{ Tonnnages } & Gross & $2,418.00$ \\
\hline & Gross on ITC & $2,761.00$ \\
\hline & Net on ITC & $1,172.00$ \\
\hline & Deadweight & $3,561.00$ \\
\hline Freeboard Summer $(\mathrm{mm})$ & \multicolumn{2}{|l|}{1810} \\
\hline Draft $(\mathrm{m})$ & \multicolumn{2}{|l|}{5.713} \\
\hline Speed $(\mathrm{Kt})$ & \multicolumn{2}{|l|}{13} \\
\hline Propulsion System of Ship & \multicolumn{2}{|c|}{ Single screw diesel engine } \\
\hline Overall Length (m) & \multicolumn{2}{|l|}{91.5} \\
\hline Place of Build & \multicolumn{2}{|c|}{ TONGYEONG } \\
\hline Date of Build & \multicolumn{2}{|l|}{$29-10-2003$} \\
\hline
\end{tabular}

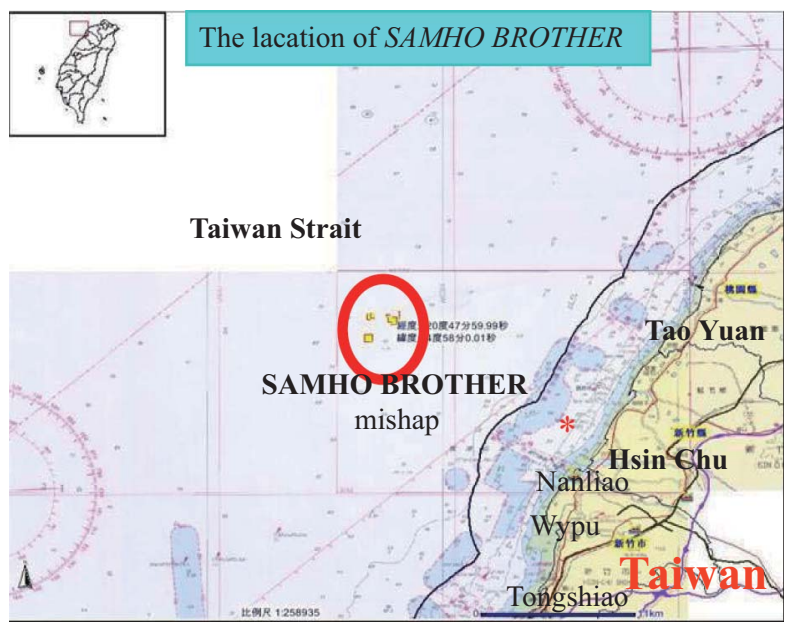

Fig. 1. The location of SAMHO BROTHER mishap in Taiwan Strait. The red star represents the weather buoy of Central Weather Bureau.

owner to rapidly manage the sunken ship and to control the spread of the oil spill.

The HRC demanded that the ship owner should immediately act to remove the cargo from the stricken vessel. To achieve this, the ship owner proposed either immediately blowing the vessel up to burn off the benzene, or waiting for sea conditions to improve and then removing the benzene by some other method. The HRC, formed by related experts called upon by the Environmental Protection Administration (EPA), agreed with that blowing the vessel up to burn the cargo was a feasible proposal based on prudent consideration of the available options, and of the desirability of acting swiftly. Benzene has a low burning temperature, and only $0.07 \%$ dissolves in water, and thus it was assumed that it was rapidly burned off following the explosion. Even when benzene evaporates into air, it rapidly dissipates in sunlight and heat.

At 06:45 on October $27^{\text {th }}$, two air force F16 fighter planes carrying four missiles made two attempts to explode the vessel, 


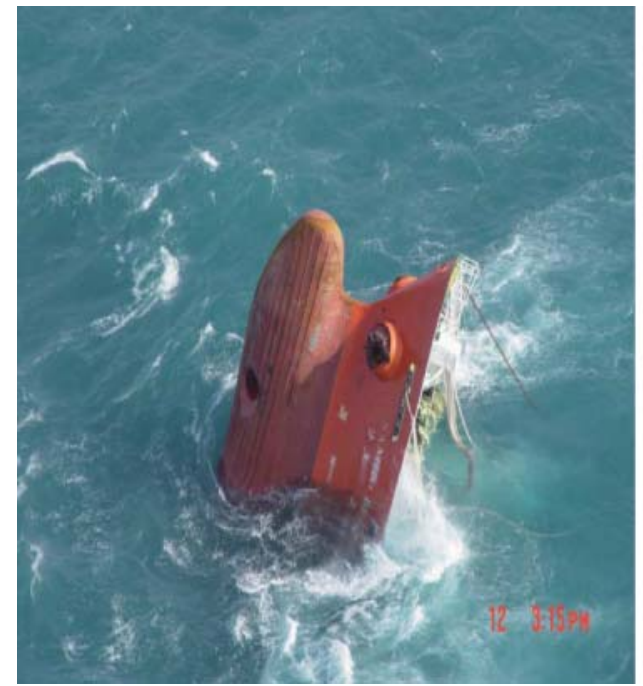

(a)

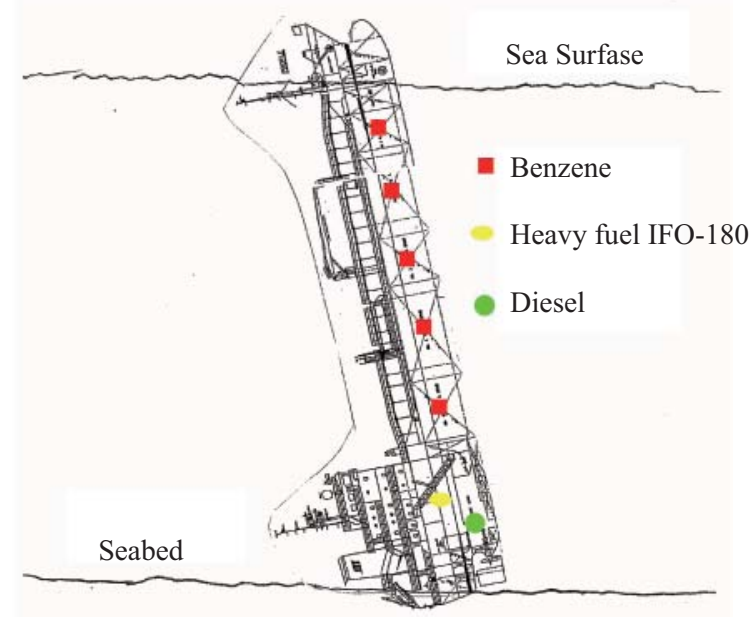

(b)

Fig. 2. (a) SAMHO BROTHER sunk with its bow surging above the water two days after collision; (12/10/2005 CGA), (b) The estimated situation of the ship wreck according to the water depth and vessel length.
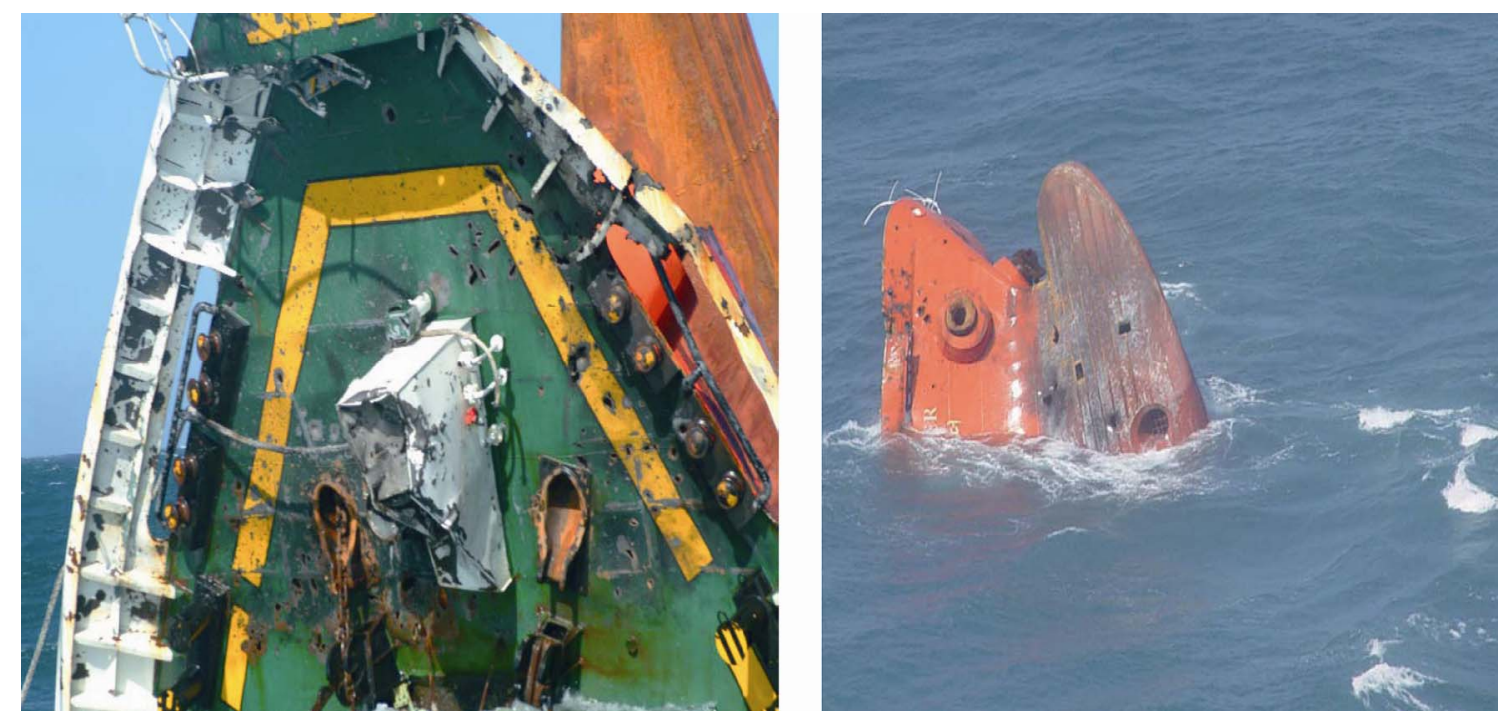

Fig. 3. The results of SAMHO BROTHER wreck after shot by missiles. (27/10/2005, CGA)

but failed to hit the target. Meanwhile twelve cutters and boats and ten oil recovery boats were standing by within a $10 \mathrm{~nm}$ radius to deal with any possible emergencies. At 16:10, two more ship explosion attempts were made by the army helicopters. Unexpectedly however, the SAMHO BROTHER suffered minor damage to the emerged hull in the bow (Fig. 3), and neither exploded nor sank. Until October $30^{\text {th }}$, it was finally found disappeared but with $200 \mathrm{~m}$ long and $10 \mathrm{~m}$ wide grey oil slick on the sea surface. On November $2^{\text {nd }}$, the wind weakened, and the HRC authorized National Taiwan Ocean University to dispatched its research vessel, Ocean Researcher 2 (R/V OR2), together with a naval mine hunter to conduct underwater detection of the sunken vessel. The SAMHO
BROTHER was found lying horizontally on the seabed, with its bow pointing towards the southwest and resting on its starboard side (Fig. 4). The nine benzene storage troughs appeared free of distortion or cracks.

Derivative problems arise. An important question was the arrangement of the nine benzene storage tanks on the SAMHO BROTHER whether the benzene should be cleaned up or could safely be left to be disposed of naturally. Additionally, although the ship owner had successfully commissioned specialized agencies to remove the 80 tons of fuel oil that leaked from the vessel using traditional recovery tools such as absorbents and oil booms, how to detect and deal with oil possibly remaining on the ship requires further investigation. 


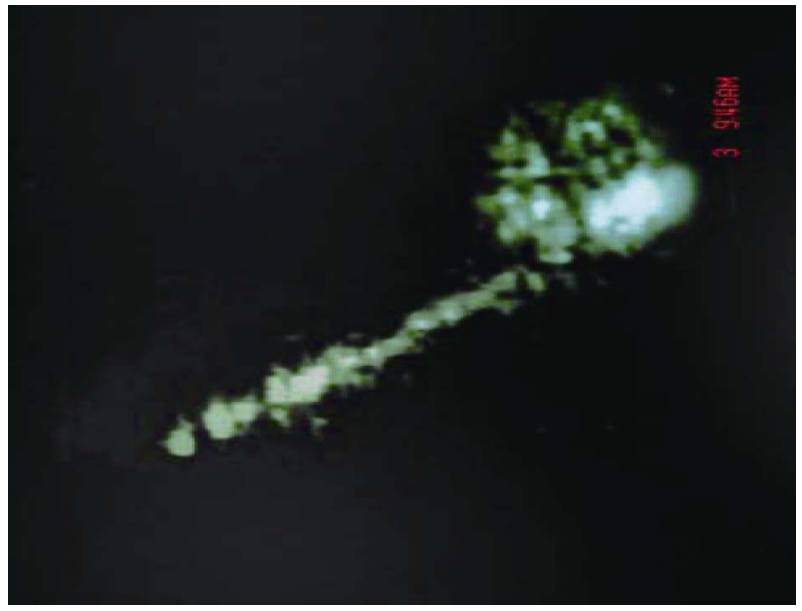

Fig. 4. The image of $S A M H O B R O T H E R$ sunk at the depth of $70 \mathrm{~m}$. The side scan taken by R/V Ocean Researcher 2 of National Taiwan Ocean University. (25/10/2005, R/V OR2)

\section{FOLLOW-UP OBSERVATIONS}

From Oct $11^{\text {th }}$ to November $30^{\text {th }}, 2005$, eight ORBs (oil recovery boats) were sent to the disaster site to recover spilled oil. During the same period, the HRC dispatched two daily helicopter patrols, at 9 am and 3 pm, together with several cutters and research vessels, to alert, film, observe, and draw testing samples for documentation and analysis. The contents of reports included the records for the spreading and recovering of spilled oil, the air and water qualities, ..., etc.

\section{Oil Dissipation}

According to statements given by the captain and chief engineer of the SAMHO BROTHER, as well as the investigative report compiled by the Taichung Harbor Bureau, at the time of abandonment the vessel was carrying 59.4 tons of heavy fuel oil, 16.7 tons of diesel, and 4.9 tons of lubricating oil, for a total of 81 tons of oil. Although all the fuel tanks were properly closed, fuel oil gradually spilled out after the ship became grounded. However the area and quantity of the spillage were limited, indicating that the oil reservoirs remained undamaged. Table 3 lists the daily observation records.

\section{1) Oil Spillage Evaluation}

Oil spills at sea undergo a series of physical and chemical processes, including evaporation, spread, dispersion, emulsification, dissolution, oxidation, sedimentation, biodegradation, ..., etc. When oil spills onto the surface of the ocean, its volume will rapidly reduce and then expand owing to the first few processes as listed above. The research of the Oil Spill Response Limited (OSRL, http://www.oilspillresponse.com /services/index.html) in England found that for a volume of $100 \mathrm{~m}^{3}$ surface oil spill, $40 \%$ would evaporate and $10 \%$ would spread and disperse, therefore $50 \mathrm{~m}^{3}$ would remain and emul- sify into a mousse, increasing in mass by four times as a result, to reach about $200 \mathrm{~m}^{3}$ and eventually to be removed by other processes. Simply put, approximately $50 \%$ of spilled oil is lost before emulsification. In fact, the quantity of oil lost may be even larger owing to the agitation of wind and waves during poor sea conditions.

Since the SAMHO BROTHER mishap on November $30^{\text {th }}$, the HRC calculated the total quantity of recovered oil as 26.156 tons prior to incineration. Based on the physical and chemical processes of oil spill, the quantity of oil prior to emulsification should be 26.156 tons $\div 4=6.54$ tons. However, as listed in Table 2, the sea conditions in the Taiwan Strait are extremely difficult during the northeast monsoon in winter. In general, the oil lost at sea at early stage after spilling could be subjectively estimated at approximately $80 \%$ rather than $50 \%$. The recovered oil thus may account for only $20 \%$ of total spilled oil, and thus could be estimated as 6.54 tons $\div$ $20 \%=32.7$ tons. Since the total fuel oil carried on the vessel was 81 tons, the sunken ship continued to carry approximately 45 to 50 tons. This amount of remaining oil may spill out in future if the wreck moves significantly to cause further damages of oil reservoirs either under oceanic motions or further human actions. The mousse, emulsified oil mixed with water, would cause the viscosity of spilled oil to increase, and therefore enhances the difficulty for cleaning up and consequently affects the ecosystem. The latent peril brought by the remained oil thus must be under control.

\section{2) Latent Peril Associated with Remaining Oil}

After the SAMHO BROTHER accident, the HRC demanded the ship owner contract specialized agencies to conduct oil blockage and recovery. Until November $30^{\text {th }}, 50$ days after the ship mishap, no more oil spillage was detected on the sea surface. The disaster was thus considered to be under control, and it was assumed that oil had stopped leaking from the vessel. Information on air and sea conditions collected during the oil spill monitoring period provided the opportunity to examine and estimate the probability of further spillage occurring and thus assist in latent crisis control.

Based on the OSRL method for estimating oil spillage, oil on the sea surface generally drifts at the same speed and in the same direction as the prevailing ocean current. However, since spilled oil is floating on the surface, such surface oil is also affected by surface winds and dragged leewards at a speed of about $3 \%$ of wind speed. In other words, the oil spill on the sea surface will dissipate as a vector sum of ocean current and wind at sea surface.

According to the database of the National Center for Ocean Research (NCOR) in Taiwan (http://www.ncor.ntu.edu.tw/odbs/ index.html), the mean sea current at a depth of $20 \mathrm{~m}$, $120^{\circ} 52^{\prime} 30^{\prime} \mathrm{E}, 24^{\circ} 52^{\prime} 30^{\prime \prime} \mathrm{N}$, is $\mathrm{u}=12.4 \mathrm{~cm} / \mathrm{s}$ and $\mathrm{v}=20.0 \mathrm{~cm} / \mathrm{s}$ (Fig. 5). This velocity is equivalent to $23.5 \mathrm{~cm} / \mathrm{s}$ for speed and $32^{\circ}$ for direction (i.e., roughly towards the northeast). In addition, the statistic rose diagram (Fig. 6) of current measurements for nearby areas taken by RV/OR2 in October, 2005 
Table 2. Observation and disposition log on oil spill in SAMHO BROTHER mishap.

\begin{tabular}{|c|c|c|c|c|c|}
\hline Stage & Date & Location & Sea State & Oil Spill State & Conduct \\
\hline \multirow{5}{*}{ One } & $\begin{array}{l}\text { Oct } 11,2005 \\
16: 30\end{array}$ & $\begin{array}{l}24.58^{\circ} \mathrm{N} \\
120.48^{\circ} \mathrm{E}\end{array}$ & Poor & $\begin{array}{l}\text { Light, silvery oil slick, floating, } 5 \mathrm{~nm} \\
\text { around mishap site. }\end{array}$ & Small amount of oil recovery. \\
\hline & Oct 15 & $\begin{array}{l}25.01^{\circ} \mathrm{N} \\
120.50^{\circ} \mathrm{E}\end{array}$ & Poor & $\begin{array}{l}\text { Silver oil film expanded } \\
900 \times 50 \mathrm{~m} \text { oil slicks. }\end{array}$ & ORBs working on oil recovery. \\
\hline & Oct $17-22$ & & $\begin{array}{l}\text { Wave 6-9 m } \\
\text { Wind 7-9 B* } \\
\text { Gust } 11 \mathrm{~B}\end{array}$ & $\begin{array}{l}\text { No observation conducted due to } \\
\text { typhoon. }\end{array}$ & Small amount of oil recovery. \\
\hline & Oct $20-22$ & $\begin{array}{l}24.57^{\circ} \mathrm{N} \\
120.47^{\circ} \mathrm{E}\end{array}$ & Poor & No oil detected from the air. & \\
\hline & Oct $23-24$ & $\begin{array}{l}24.58^{\circ} \mathrm{N} \\
120.47^{\circ} \mathrm{E}\end{array}$ & Improved & $\begin{array}{l}\text { Found new oil slick } \\
200 \times 10 \mathrm{~m} \text { silver white oil slicks. }\end{array}$ & ORBs working on oil recovery. \\
\hline \multirow{4}{*}{ Two } & Oct 27 & $\begin{array}{l}25.01^{\circ} \mathrm{N} \\
120.50^{\circ} \mathrm{E}\end{array}$ & Good & $\begin{array}{l}06: 45 \text { air force F16 and 16:06 army } \\
\text { helicopter took two rounds of } 4 \text { missile } \\
\text { shootings. } 12 \text { vessels guarded and } \\
\text { monitored. Ship wreck did not sink } \\
\text { after shooting. }\end{array}$ & $\begin{array}{l}\text { RV/OR2 and CESH closely } \\
\text { monitored the site before and } \\
\text { after the shooting. Benzene } \\
\text { leakage was not found. Oil } \\
\text { recovery continues. }\end{array}$ \\
\hline & Oct 27-Nov 16 & $\begin{array}{l}24.58^{\circ} \mathrm{N} \\
120.47^{\circ} \mathrm{E}\end{array}$ & Improved & $\begin{array}{l}\text { Oil slicks enlarged to be } 7 \mathrm{~km} \text { long and } \\
50-100 \mathrm{~m} \text { wide. Yellowish to dark } \\
\text { brown oil slicks spread northward from } \\
\text { south to the sea at Taoyuan. Nearest to } \\
\text { the coast is } \sim 9 \mathrm{~nm} \text {. }\end{array}$ & ORBs working on oil recovery. \\
\hline & Nov $17-23$ & $\begin{array}{l}24.58^{\circ} \mathrm{N} \\
120.47^{\circ} \mathrm{E}\end{array}$ & $\begin{array}{l}\text { Poor, strong } \\
\text { winds and } \\
\text { waves }\end{array}$ & $\begin{array}{l}\text { Air observation. Oil slicks has been } \\
\text { scrambled and dispersed to disappear. }\end{array}$ & ORBs stopped working. \\
\hline & Nov 25 and after & $\begin{array}{l}24.58^{\circ} \mathrm{N} \\
120.47^{\circ} \mathrm{E}\end{array}$ & $\begin{array}{l}\text { Improved } \\
\text { slightly, still } \\
\text { poor }\end{array}$ & $\begin{array}{l}\text { Oil was found from time to time near } \\
\text { the site. }\end{array}$ & $\begin{array}{l}\text { Oil reduced. No oil recovery in } \\
\text { few days. }\end{array}$ \\
\hline
\end{tabular}

*B stands for Beaufort Scale.

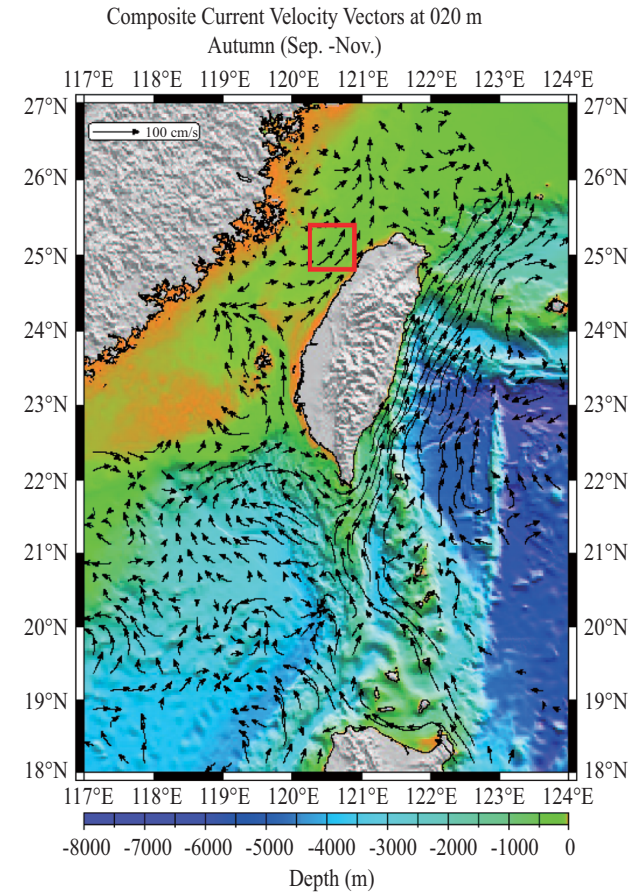

Fig. 5. Seasonal mean currents around Taiwan in autumn. (Information source: National Center of Ocean Research). The red square indicates the location of the ship wreck.

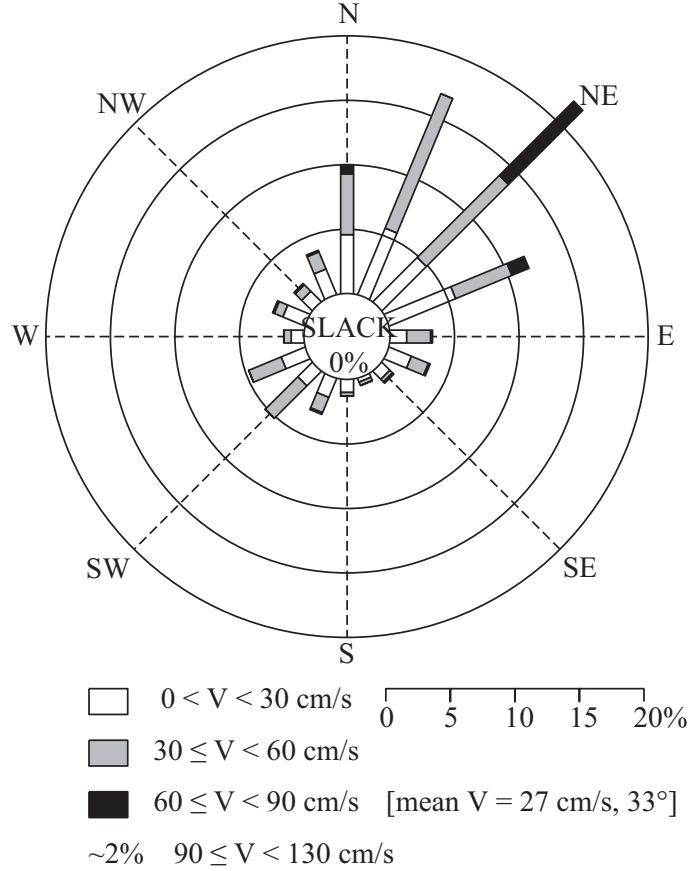

Fig. 6. The statistics in rose diagram for the one day currents observed by the ADCP on RV/OR2 at the depth of $20 \mathrm{~m}$ around the ship mishap in October, 2005. 


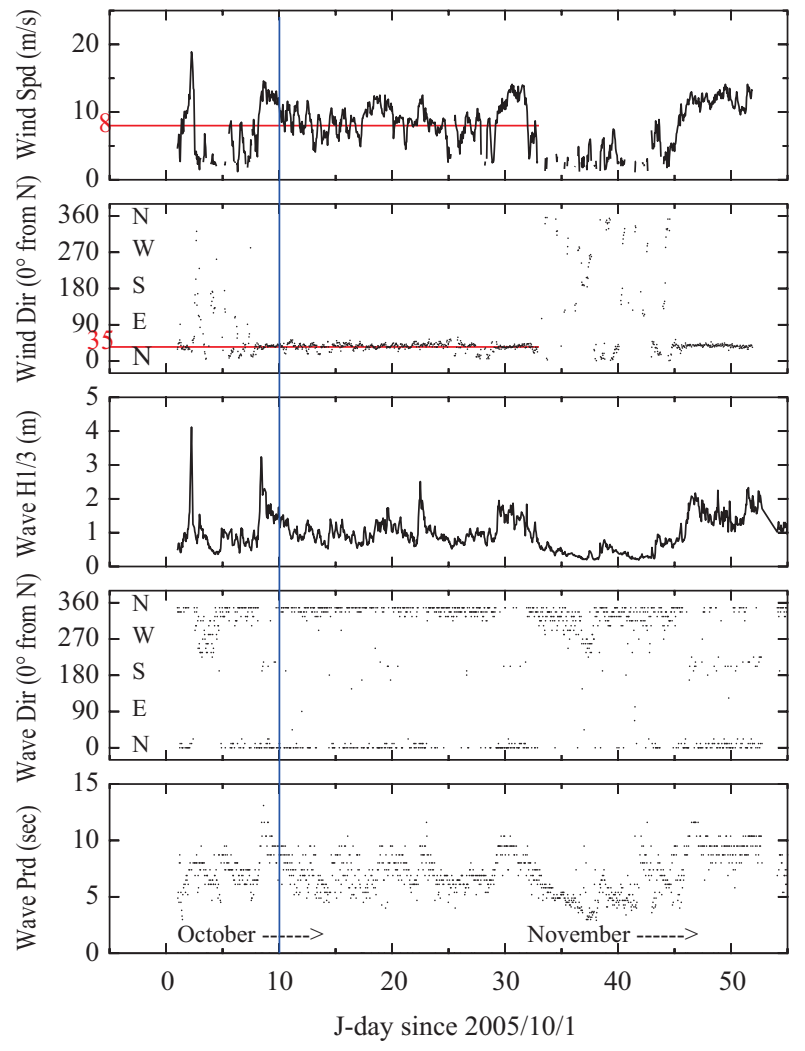

Fig. 7. Information of winds and waves observed by the weather buoy located as shown in Fig. 1.

shows that the coastal current directions mainly lie from the north to the east with a mean direction of $33^{\circ}$ and a mean speed of $27 \mathrm{~cm} / \mathrm{s}$. These two current assessments thus agree with each other to a good extent. Accordingly, the leaked oil should have been traveling at $10 \mathrm{~nm}$ per day towards the north northeast.

On the other hand, the Central Weather Bureau of Taiwan maintains a weather buoy at $24^{\circ} 46^{\prime} 43^{\prime \prime} \mathrm{N}, 120^{\circ} 52^{\prime} 48^{\prime \prime} \mathrm{E}$, indicated by * in Fig. 1, a position $1.5 \mathrm{~km}$ from the coast with a water depth of $22 \mathrm{~m}$. The recorded wind field from October to November is shown in Fig. 7. Table 2 shows that the oil spill failed to display any recovery from October $11^{\text {th }}$ to $15^{\text {th }}$. During this five day period, Fig. 6 indicates that the strongest wind speed during the northeast monsoon was about $10 \mathrm{~m} / \mathrm{s}$, while the mean wind speed was $7 \sim 8 \mathrm{~m} / \mathrm{s}$ and the direction was $35^{\circ}$. Therefore, the wind leeward effect upon oil floating on the sea surface should have had a magnitude of $10 \mathrm{~nm}$ per day to the south southwest. In other words, the vector sum of current drift and wind drag should have become zero, meaning that the area of oil contamination should have stopped growing. The area of oil spill condition in Table 2 indicates a similar signal that the oil effluent did not leave the area of the accident, demonstrating that the above estimate, based upon air and sea conditions, is rational.

However, Table 2 also indicates that the oil spill had the form of a strip roughly mirroring the orientation of the western coastline of Taiwan. Besides the opposite effects of mean current and wind drag, this phenomenon should also result from reciprocating flood tides and ebb tides. It was mentioned therein before that the resultant flow of mean and semi-diurnal tidal currents on the western coast of Taiwan could be estimated as $25 \mathrm{~cm} / \mathrm{s}$. Therefore, for the same phase of about 6 hours, the oil spill could be extended by the reciprocating tidal currents for about $5.4 \mathrm{~km}$, not too different from the observed elongation of $7 \mathrm{~km}$, as shown in Table 2. This successful approach proves the reliability of that the latent peril of further dissipation of remained oil, such as whether the effluent will be drifted far away or merely elongated at local place, can be predicted by the air and sea conditions. Accordingly, this approach will also benefit the planning of contamination tracking, blocking, and recovering processes.

\section{Detection of Benzene Leakage}

Benzene is a highly volatile, flammable, toxic, and carcinogenic fluid. It releases toxic gases such as carbon monoxide during inflammation. Health hazards exist in the form of pathological changes to the skin at benzene concentrations exceeding $5 \mathrm{ppm}$ in air, and the hazard becomes immediately life threatening with an excess of $500 \mathrm{ppm}$. Hence, the ROC EPA has regulated $5 \mathrm{ppm}$ as the maximum allowable concentration of benzene in air, while in water the level is set at 10 ppm [7].

Following the mishap, the HRC immediately commissioned the Center for Environmental Safety and Health Technology Development (CESH) to collect water and air samples for benzene testing. CESH personnel began drawing samples from the south side of the ship wreck (the leeward side during the northeast monsoon) from Oct $11^{\text {th }}$ to $14^{\text {th }}$, and then conducted more comprehensive surveys on October $15^{\text {th }}$. Afterwards, three observation stations located about $800 \mathrm{~m}$ away from the accident site in different directions named north Station \#1, east Station \#2, and south (leeward) Station \#3.

Monitoring of sea air was conducted in advance using a portable Photoionization Detector [14] on ORBs by detecting the total volatile organic compound (TVOC). Abnormalities were taken to indicate benzene leakage from the shipwreck, and thus water samples of wherever were immediately gathered in stainless steel containers and sent to the lab for further analysis using Gas Chromatograph/Mass Spectrometer (GC/MS) [8]. Meanwhile, regardless of the results of real-time air monitoring, the benzene concentration of water was routinely measured using GC/MS at the three stations. Coastal monitoring systems were established separately at three fishing ports, Nanliao in Hsinchu, and Wypu and Tongshiao in Miaoli (Fig. 1). At these ports, a similar method was applied to measure benzene concentration in sea water while the large equipment of Open-path Fourier Transform Infrared (OP-FTIR) [18] was set up to continuously monitor airborne benzene concentration.

Since the HRC decided to attempt to blow the vessel up on October $27^{\text {th }}$, monitoring and testing tasks were suspended 
Table 3. The $1^{\text {st }}$ stage in situ air concentrations of benzene before bombing SAMHO BROTHER.

\begin{tabular}{|c|c|c|c|}
\hline Date Position & North Station \#1 & East Station \#2 & $\begin{array}{l}\text { South Station \#3 } \\
\text { (leeward in NE monsoon) }\end{array}$ \\
\hline October 11 & - & - & $0.015 \sim 0.020 \mathrm{ppm}$ \\
\hline October 12 & - & - & $0.015 \sim 0.020 \mathrm{ppm}$ \\
\hline October 13 & - & - & $0.010 \sim 0.015 \mathrm{ppm}$ \\
\hline October 14 & - & - & $0.015 \mathrm{ppm}$ \\
\hline October 15 & - & - & $\begin{array}{l}\text { Mean in the morning } 0.502 \mathrm{ppm} \text {, the highest } 3.42 \mathrm{ppm}(800 \mathrm{~m}) \\
\text { Evening } 0.015 \mathrm{ppm}(360 \mathrm{~m})\end{array}$ \\
\hline October 16 & - & - & $0.150 \sim 0.200 \mathrm{ppm}(800 \mathrm{~m})$ \\
\hline October 17 & - & - & $0.060 \sim 0.120 \mathrm{ppm}(360 \mathrm{~m})$ \\
\hline October 18 & \multicolumn{3}{|c|}{ Wind waves too high to sail out. } \\
\hline October 19 & \multicolumn{3}{|c|}{ Wind waves too high to sail out. } \\
\hline October 20 & \multicolumn{3}{|c|}{ Wind waves too high to sail out. } \\
\hline October 21 & - & - & - \\
\hline October 22 & $0 \sim 0.009 \mathrm{ppm}$ & $0 \mathrm{ppm}$ & $0.001 \sim 0.005 \mathrm{ppm}$ \\
\hline October 23 & $0.003 \sim 0.008 \mathrm{ppm}$ & $0.003 \sim 0.008 \mathrm{ppm}$ & $0.001 \sim 0.005 \mathrm{ppm}$ \\
\hline
\end{tabular}

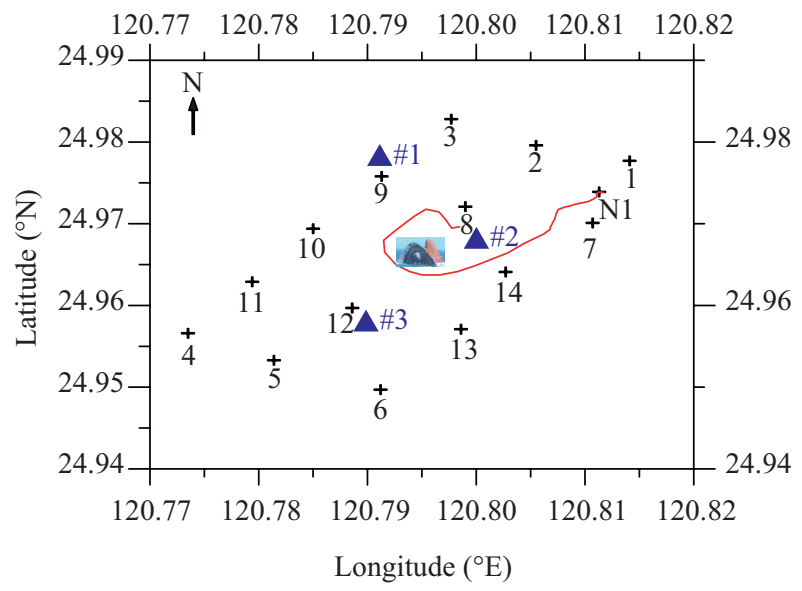

Fig. 8. The 3 stations (blue triangles) for water and air samplings during Oct. 11 - Nov. 30 taken by CESH and the 14 stations by RV/OR2 before the explosion operation on October $26-27^{\text {th }}$ in 2005 . Water samples were also taken along the red cruise line after the explosion.

temporarily. Therefore, the period from October $11^{\text {th }}$ to $23^{\text {rd }}$ was considered the first stage in the benzene monitoring (Table 2). Before and after the explosion, from Oct $26^{\text {th }}$ to $29^{\text {th }}$, the R/V OR2 was sent to the disaster area to conduct a close investigation. Investigation revealed that the benzene aboard the ship had failed to ignite, and the ship had sunk to the bottom of the ocean on October $30^{\text {th }}$. Since it was difficult to confirm whether the benzene tanks had been damaged to cause leakage, the R/V OR2 visited the accident site again on November $1^{\text {st }} \sim 2^{\text {nd }}$ to make another survey. Subsequently, only minimal and scattered in situ surveys were performed, given constraints resulting from sea conditions and other factors. Nonetheless, coastal monitoring continued until November $30^{\text {th }}$, and was known as the second stage in the benzene monitoring (Table 2).

At the first stage from October $11^{\text {th }}$ to $15^{\text {th }}$, the monitoring results revealed that the maximum concentration of airborne benzene was $0.128 \mathrm{ppm}$, while the waterborne concentration was extremely low, at just $0.021 \mathrm{mg} / \mathrm{L}$. Thus, while there appeared to have been some benzene leakage, the recorded environmental levels were well within the $5 \mathrm{ppm}$ set by the EPA. Notwithstanding, none of the other factors examined exhibited an alarming concentration either. As for the airborne concentration of benzene at the site as listed in Table 3, the peak concentration was the $0.20 \mathrm{ppm}$ detected on October 16, which was also well below the EPA allowed airborne concentration.

At the second stage, a few days following the missile operation from Oct $27^{\text {th }}$ to November $2^{\text {nd }}$, a small quantity of benzene continued to be detected in the water near the sunken vessel. The highest concentration was $0.003 \mathrm{mg} / \mathrm{L}$, consistent with small-scale benzene leakage, but the concentration was reduced greatly from the amount detected at the first stage. After a month of monitoring, benzene was not detected in the water any more. As for airborne benzene concentration, the highest level was $0.004 \mathrm{pm}$, considerably lower than the $5 \mathrm{ppm}$ set by the EPA. Benzene was not detected in the air or water in the nearby coastal region, and no damage to life was sustained along the coast.

The close monitoring and testing right after and before the missile attack included works implemented by $\mathrm{CESH}$ and the $\mathrm{R} / \mathrm{V}$ OR2's intensive surveys of airborne and waterborne benzene contamination in the area surrounding the site of the accident. From 17:00 to 24:00 on October $26^{\text {th }}$, R/V OR2 collected water samples at depths of $0 \mathrm{~m}, 25 \mathrm{~m}$, and $70 \mathrm{~m}$ at 14 stations (Fig. 8) in a $0.5 \mathrm{~nm}$ radius of the ship wreck. Among various testing items, benzene detection was again performed 


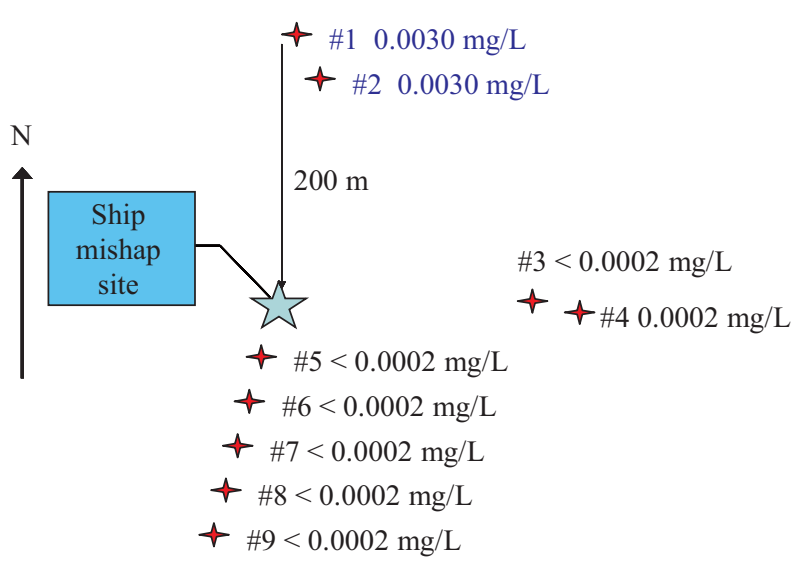

Fig. 9. The results and locations for detecting air concentration of benzene performed by CESH on Oct. $27^{\text {th }}, 2005$ after the explosion of the ship wreck.

using the GC/MS method. The detection threshold was $0.0002 \mathrm{mg} / \mathrm{L}$, and the results were all ND (none detectable). At dawn on October $27^{\text {th }}$, the missile attack started. At 10:20, the R/V OR 2 entered the area of about $0.2 \mathrm{~nm}$ radius of the site (the red cruise track in Fig. 8) to collect eight water samples, and once again failed to detect any benzene. Additionally, CESH also entered the same area at 07:40 and tested for airborne benzene. Figure 9 shows the testing stations and results. The results were mostly ND with the exceptions of Stations 1, 2 , and 4 which were far below the standard set by the EPA again.

\section{COUNTERMEASURES}

After the SAMHO BROTHER was attacked by missiles, the benzene and fuel oil were not ignited, the latent danger remained unresolved, and thus a final clean up operation is still needed. In the past, there were numerous instances of ships sunk, but salvaging or exploding sunken ships was only rarely considered due to technological difficulty, mainly being confined to situations where the wreck was considered a hazard to other shipping, where the wreck contained valuables, or where there was an environmental risk. Recently, the underwater technology advances greatly, and thus searching and salvaging of sunken ship is becoming increasingly common.

Based on previous estimates, approximately an amount of 50 tons fuel oil remains inside the wreck. This figure corresponds with the 55 tons estimate remained in the oil reservoir near the starboard side, the number given by specialists of the International Tanker Owners Pollution Federation (ITOPF), the organization commissioned by the insurance company of the ship owner. If all of the fuel leaks out during subsequent operations, the catastrophic extent is still considered limited and controlled. Restated, the area and intensity of spillage associated pollution can be estimated and calculated if the air and sea conditions such as ocean currents, winds, and tides are available. In addition, adequate information on the water qual- ity and environmental ecosystem of the site must be collected to serve as a basis for making follow up comparisons in identifying responsibility of the accident. Therefore, any selected scheme would depend for its success on the availability of such related information.

Benzene is the most problematic aspect of this accident, with the vessel carrying a significant quantity. The accident was unprecedented locally and internationally in history, and thus no duplicate experience or information was available. The Japanese benzene ship M/T Kyokuyo-Maru exploded after catching fire as a result of the initial collision in July, 2005 and thus fuel oil and benzene carried on board were entirely burned out before the ship was towed out to sea and sunk. The situation still differed from SAMHO BROTHER, which sank with its nine benzene tanks completely intact.

In the history of maritime disasters, the most difficult and dangerous case was undoubtedly the salvaging of the Kursk, the Russian nuclear submarine. The submarine sank on Aug. $12^{\text {th }}, 2000$, and its salvage attracted global attention. In order to quickly eliminate the risk associated with leakage of radioactive materials, the Kursk Foundation was established three months after the disaster to raise funds, plan, and monitor the salvage operation. An alliance was established among international salvage companies, and before the operation, the Russian Academy of Sciences carried out large scale simulation and integrated testing to determine when was the appropriate time for salvaging and transporting the submarine with twenty-two Granit cruise missiles carried on board. In addition, computer simulations were performed to test the procedures and techniques used for deep water salvage, and deep water divers drilled using a similar nuclear submarine for the dangerous and complicated salvage procedures. The entire operation cost 80 million USD.

To the mishap, subsequent handling of the SAMHO BROTHER and its hazardous cargo must comply with ROC's law, which regulates that ship owners need to assume full responsibility for releasing the environmental impact. Meanwhile, the relevant authorities, such as the EPA and the Ministry of Transportation \& Communications should be in charge of supervising and implementing tasks like comprehensive security protection and emergency rescue in any further operation of the ship wreck. After the accident, two possible responses were initially proposed, namely to raise and tow the ship away or to blow it up with explosives on site.

Nevertheless, the sea conditions were poor when plans were made for the vessel to be towed, while there was considerable uncertainty attached to an alternative proposal to delay salvage operations until the summer. A delay in dealing with the problem would also have placed the ROC government under pressure from concerned citizens. Therefore after discussion, on-site bombing from the air was determined to be the acceptable approach in considering people's life safety in cleaning operation. However, the results were not as anticipated. The ship wreck sank to the bottom of the sea with no explosion. At that time, the ship owner and ROC government 
officials conferred and agreed to take further actions during the summer of the following year when the sea condition steadied. Yet, at the time of writing, there was no promised action having taken place, possibly because the two parties failed to reach a consensus on a practical implementation. Based on the international experience of dealing with sunken vessels carrying dangerous substances, as well as the Taiwan's oceanic condition, four possible responses for dealing with the aftermath of the disaster are described below.

\section{No Further Action}

In this scenario no further action would be taken to treat the sunken ship. That is, the accident would be treated as a regular maritime disaster, and the forces of nature would be allowed to run their course in dealing with the ship and its cargo. Maybe it is the cheapest way to do in the short term, and given that the ship is lying at a depth of $70 \mathrm{~m}$, it represents a hazard for shipping immediately. Nonetheless, the potential for a disaster for local fisheries remains. After several years, when the ship has corroded, the fuel oil within the vessel may spill out. Therefore, long term monitoring of the local oceanic environment should be implemented for possible oil pollution.

On the other hand for benzene onboard, the nine storage tanks would have been tightly sealed before the accident, and the ship is just four years old at present (Table 1). It means that the tanks should remain safe for about ten more years in sea water. Nevertheless, any event of a major leak, although only approximately $0.07 \%$ of the benzene dissolved in water, would lead to the continuing possibility of toxic sea water affecting nearby marine life and ecosystems. In such a case, most of the benzene would rise to the sea surface and dissipate to the air, with the course of the wind, being blown towards the coast to endanger the health of coastal habitants. The influence of such a spill is difficult to forecast owing to the lack of relevant knowledge, controversies between the ship owner and the ROC government might therefore arise.

As a consequence of uncertainties, the authorities must establish a long-term team of specialists to monitor the potential for environmental disaster. The total costs must come from the insurance company of the ship owner, and a guarantee fund to ensure adequate handling of long-term environmental influence should be deposited in bank as a credit. Even though, the remains of the ship will become a nightmare for the coastal environment, and therefore, taking no further actions is not the optimal response.

\section{Salvage the Ship and Its Cargo}

Since benzene is flammable, there is a constant risk of explosion, making any salvage operation involving the SAMHO BROTHER highly dangerous. According to the case of Kursk, comprehensive testing and preparation therefore should be performed before implementing any salvage operation. Such operation should be scheduled in either the summer or the fall, when air and sea conditions are good. Although the mean seasonal current in the Taiwan Strait is not strong (Fig. 5), the reciprocating coastal tidal currents are not weak. As shown in Fig. 6, flood and ebb tidal currents may reach speeds exceeding one knot, creating a challenge for divers. Generally, the seabed comprises soft sand. Under strong and variable tidal current flushing, lateral drift causes the vessel to sink easily below sands due to the weight of the ship wreck. Divers or ROV (remotely operated vehicle) may need to drill holes in the hull of the ship at a significant depth beneath the sands to secure cables for lifting, potentially an extremely hazardous procedure.

Before the operation, an international salvage supervision team must be established to perform the following tasks. (a) Investigate and gather information and data on oceanic and coastal environments within a $20 \mathrm{~km}$ radius of the sunken ship before commencing the salvaging operation. (b) Solicit the most qualified salvage company in the world to execute the operation. (c) Conduct simulation and testing of the chosen proposal. (d) Superintend the in situ salvage operation. (e) Supervise synchronized surveys on the marine environment during the salvage operation. (f) Demand environmental investtigation of the nearby oceanic and coastal regions for at least one year after the salvage operation.

In view of such a scenario, salvaging the ship along with the cargo should be able to completely eliminate the benzene hazard and thus all contingent environmental problems. Such salvage operation would be the best way to keep the coastal region away from further catastrophe. The only setback lies in the complexity of the operation, as well as the risk of explosion and costly failure. The compensation could be from either the value of the benzene in the nine tanks or the ship itself which is still quite new for repaired or sold as scraps. Nonetheless, the value of the recovered chemicals and of the vessel itself will hardly offset the costs of the operation. Therefore, the owner may be unwilling to fund such operation, possibly leading to legal action between the ROC government and the insurance company of the ship owner.

\section{Extract Fuel Oil and Benzene}

If the oil and benzene can somehow be removed from the vessel, the ship will no longer present a potential hazard to the local marine ecosystem, making salvage unnecessary. The ship wreck could even become a benefit to the surrounding ecosystem in the form of an artificial fishing reef. The operation cost may thus become much lower than that of the second scenario discussed above. In fact, the water depth of $70 \mathrm{~m}$ always causes technical difficulties for divers. Compared to the second scenario, lifting the ship wreck will no longer be necessary making the extracting operation much easier. However, the need to directly contact the benzene tanks added another risk factor to such operation.

The implementation of this countermeasure requires the same careful preparation, evaluation, and supervision as the second scenario. However, extensive supervision is also required for precise measurement of the quantity of oil and benzene extracted. If the measurement reveals that the fuel oil 
and benzene have not been completely extracted, possible environmental problems resulting from leakage of the remaining in the ship wreck still exist. If such a case happened, the ship wreck would still need to be salvaged and lifted, at considerable difficulty and expense again. The ROC authorities in charge of this matter thus may ask the owner to perform extraction first, and then evaluate the results before taking further action to salvage the wreck.

In other words, failure to succeed in this operation may mean that the second scheme then has to be performed anyway. However, this method at least gives the ship owner an opportunity of following this scheme only, if a complete extraction of oil and benzene is proved. Therefore, the key is the method used to extract the substances, and then to assess the results. Any disagreement between the ship owner and ROC government with the assessments of oil and benzene extractions would result in another endless legal controversy.

\section{Complete Underwater Explosion}

The initial response to the accident was to blow up the ship using missiles. This idea was chosen because it was hoped that blowing up the ship would ignite the highly flammable benzene the ship was carrying, thus reducing the pollution to a minimal extent. On the whole, burning would quickly resolve the danger of the chemical ship, therefore, it should still be considered as an acceptable approach aside from abandoning the shipwreck. However, the attempt to ignite the dangerous cargo in the sinking ship further complicates the situation.

Now the ship can only be effectively blown up by either using explosives placed by divers or a torpedo shot from a distance. At the depth of $70 \mathrm{~m}$, the former involves advanced techniques and the uncertainty of explosion danger, while the latter requires a sound source on the sunken ship which can be installed by a ROV or divers. However, the latter may cause another miss shot and greatly increase the risk of further operations. Therefore using a torpedo is less desirable than placing explosives using human divers owing to the lower precision.

In addition, underwater explosion involves another uncertainty, namely how the benzene will react when the tanks are exploded. Will it explode and burn out instantaneously to become harmless or upwell to surface and evaporate into the air? In case of any amount of benzene floating to the surface of the water, some techniques must be applied to burn it off from the surface. For example, fire sources must be set up on the surface of the water when the underwater explosion occurs so that once benzene upwells to the surface, it will be burn out immediately. The main concern is that such procedure has never been adopted. Therefore, nobody can forecast the results with any certainty. A simulated testing with small experimental amount of benzene released at bottom to be performed at sea in advance is thus suggested.

Conducting underwater explosive work requires a specialized execution team. The focus should be placed on the explosion procedure and simulation testing. However, the large quantity benzene stored in the tanks surges upwards to the surface all at once when the explosion occurs. Although the amount to be dissolved in water is thought to be limited, the area affected and the duration of the effect still cannot be well determined with current knowledge of science. Hence it is suggested that at least three years of follow up tracking on the air and sea environments of the ship mishap should be conducted. Overall, from the perspective of technical difficulty, the feasibility of this approach is highest among the proposals presented here while the risk is lowest. The entire process should be the simplest.

To summarize the four scenarios in reversed sequence: (1) Underwater explosion appears to be the most feasible option in terms of technical requirements and effectiveness, as well as being the quickest solution to implement. That is the reason for HRC to recommend the explosive approach to the ship owner initially. However, it was implemented, under the time constraints, and without careful design and study, rendering the results disappointed. (2) The technical difficulty of extracting the remaining oil and benzene at the depth of $70 \mathrm{~m}$ underwater can be overcome, but the measurement of extracted substances is critical. If the remains cannot be completely extracted, alternative method must be implemented. Therefore, extraction of benzene relies strongly on chance. (3) Although salvaging the ship and the cargo on board would be a straightforward method, it is complicated and costly, as well as being risky, and thus being unappealing to the ship owner. (4) Not taking further action to treat the ship wreck at all, the ship owner must face the long-term consequences of all kinds of risks, and the ROC government will also have to be liable for the chronic environmental pollution of Taiwan's coastal region, and therefore this approach is not recommended.

\section{V.SUMMARY AND CONCLUSION}

Marine accidents cannot be completely avoided, and oil spill hazards exist in association with such events. In the case of marine accidents involving chemical ships, the risk is considerably magnified. Oil spill occurred immediately in the case of the SAMHO BROTHER, a chemical ship laden with benzene sank in the Taiwan Strait on October $10^{\text {th }}, 2005$. Oil effluent of 35 tons was recovered. Careful estimation then determined that 50 tons of fuel oil remained in the vessel. Simultaneously, the result of the environmental monitoring indicated only limited benzene leakage occurred. Some 3,140 $\mathrm{m}^{3}$ of benzene were still stored in the nine tanks. The Taiwan Strait suffered heavy seas during the northeast monsoon. Such conditions made an immediate conventional clean up impossible, and therefore it was decided to blow up the ship with missiles to burn off as much of the benzene as possible. However, the plan failed to achieve the anticipated result. The ship and its cargo sank to the bottom of the sea at the depth of $70 \mathrm{~m}$ and the benzene failed to ignite. Therefore, further action needs to be taken to deal with the dilemma.

There are four possibilities for dealing with the sunken ship, 
including leaving the ship at its current site, salvaging the ship and its cargo, and extracting the remaining fuel oil and benzene, and/then blowing up the ship in an underwater explosion. To solely rely on the power of nature to dispose of the ship will result in substantial environmental damage, and therefore is unacceptable to the public. This will also create a long-term burden for the ship owners and insurance companies, and thus is an infeasible approach. Next, salvaging the ship and its cargo would be a rather straightforward approach, but this approach would be costly and technically difficult, so the ship owner and the insurance company may be unwilling to agree for full responsibility. The ROC's authorities attempting to request the ship owner to follow this course may result in legal delays and ultimately the losing of the two parties. The next best option is to conduct underwater extraction of the remaining oil and benzene and leave the shipwreck permanently at the bottom of the sea. The key to success of this proposal is the completeness of the extraction. If the extracted amount fails to match the total amount, then supplemental procedures must be implemented. Therefore, this scheme can only serve as the preparation procedure for the alternative approaches, except when the measurement of the extracted oil equals to or exceeds the estimate of the oil remained. The final scheme is to conduct an underwater explosion. This approach is technically feasible, quick, effective, and possibly least costly. The possibility of reaching a consensus between the ROC officials and the ship owner should be high, and therefore, this scheme deserves consideration.

When dealing with disputes arising from international marine accidents, government agencies all over the world need to be determined to achieve the best outcomes for all concerned despite conflicting pressures of political situation, criticism, and public opinion, ... etc. The parties involved in such disputes, whether intentionally or unintentionally, are typically attended to by insurance companies, and the emphasis should be placed on acceptable compensation rather than lawsuits. Consensus must be reached. The case of benzene described here was unprecedented internationally. Various considerations and experiences are valuable for international scholars in various fields, including ocean science, oceanic ecology, and underwater technologies. For example, air and sea conditions, such as coastal currents, waves, tides, and winds need to be monitored and observed over the long-term, so the data collected can provide a basis for analyzing further actions, and can be used in disaster control.

\section{ACKNOWLEDGMENTS}

Special thanks would give to those who participated in the entire rescue mission and to the reviewers of this paper for their comments and kind helps. Mr. Ted Knoy is also appreciated for his editorial assistance.

\section{REFERENCES}

1. Alvarez-Salgado, X. A., Herrera, J. L., Gago, J., Otero, P., Soriano, J. A., Pola, C. G., and Garcia-Soto, C., "Influence of the oceanographic conditions during spring 2003 on the transport of the Prestige tanker fuel oil to the Galician coast," Marine Pollution Bulletin, Vol. 53, pp. 239-249 (2006).

2. Amundsen, I., Iosjpe, M., Reistad, O., Lind, B., Gussgaard, K., Strand, P., Borghuis, S., Sickel, M., and Dowdall, M., "The accidental sinking of the nuclear submarine, the Kursk: monitoring of radioactivity and the preliminary assessment of the potential impact of radioactive releases," Marine Pollution Bulletin, Vol. 44, pp. 459-468 (2002).

3. Bethune, B., "The Kursk tragedy," Maclean's, Vol. 116, pp. 62 (2003).

4. Carracedo, P., Torres-Lopez, S., Barreiro, M., Montero, P., Balseiro, C. F., Penabad, E., Leitao, P. C., and Perez-Munuzuri, V., "Improvement of pollutant drift forecast system applied to the Prestige oil spills in Galicia Coast (NW of Spain): Development of an operational system," Marine Pollution Bulletin, Vol. 53, pp. 350-360 (2006).

5. Chen, H. Y. and Lee, Y. L., "An ecological survey on the waters adjacent to the Northern Taiwan nuclear power plant sites," National Scientific Committee on Problems of the Environment Academia Sinica, Special Issue, pp. 74 (In Chinese) (2006).

6. Chiau, W. Y., "Changes in the marine pollution management system in response to the Amorgos oil spill in Taiwan," Marine Pollution Bulletin. Vol. 51, pp. 1041-1047 (2006).

7. EPA, 2004. "Marine pollution control by Environmental Protection Administration," http://cemnt.epa.gov.tw/eng/.

8. GC/MS, "Gas Chromatography-Mass Spectroscopy Background," http://www.gmu.edu/deparments/SRIF/tutorial/gcd/gc-ms2.htm.

9. Gilfillan, E. S., Harner, E. J., O'Reilly, J. E., Page, D. S., and Burns, W. A., "A comparison of shoreline assessment study designs used for the Exxon Valdez," Marine Pollution Bulletin, Vol. 38, Issue 5, pp. 380-388 (1999).

10. Lin, C. L. and Hu, J. H., "SAMHO BROTHER benzene ship accident," Marine Pollution Bulletin, Vol. 54, pp. 1285-1286 (2007).

11. Louis, A., "Kursk down," Military Law Review, Vol. 176, pp. 459-466 (2003).

12. Mitja Gregorič, "Two tankers collided-chemical tanker carrying 1,000 tonnes of creosote," http://ctif-hazmat.gasilci.org/modules/news/article. php?storyid=87 (2005).

13. Petit, C. W., "Raising the Kursk," U.S. News \& World Report, Vol. 131, No. 5, pp. 40 (2001).

14. PID, Introduction Photoionization Detector, http://www.shsu.edu/ chemistry/PID/PID.html.

15. Shao, K. C., "The comments of ship mishap oil contamination disposal incident," National Policy Research Foundtion, http://old.npforg.tw/ PUBLICATION/SD/090/SD-R-090-004.htm (In Chinese) (2001).

16. Shigenaka, G., Hayes, M. O., Michel, J., Henry, C. B. Jr., Robert, P., Houghton, J. P., and Lees, D. C., "Integrating physical and biological studies of recovery from the Exxon Valdez oil spill-case studies of four sites in prince william sound," 1989-1994 National Oceanic and Atmospheric Administration Hazardous Materials Response and Assessment Division, pp. 238 (1997).

17. Stekoll, M. S. and Deysher, L., "Response of the dominant alga fucus gardneri (Silva) (Phaeophyceae) to the Exxon Valdez oil spill and cleanup," Marine Pollution Bulletin, Vol. 40, pp. 1028-1041 (2000).

18. Yang, J. C. and Chang, P. O., "Fourier transform infrared, FTIR," Center for Environmental Safety \& Health Technology Development, Industrial Technology Research Institute. (In Chinese) (2002). 